\title{
Oligo-fucoidan improved unbalance the Th1/Th2 and Treg/Th17 ratios in asthmatic patients: An ex vivo study
}

\author{
CHAO-HUEI YANG ${ }^{1 *}$, JING-JING TIAN ${ }^{2 *}$, WANG-SHENG KO ${ }^{1,2}$, CHIA-JU SHIH ${ }^{2}$ and YA-LING CHIOU ${ }^{2}$ \\ ${ }^{1}$ Department of Internal Medicine, Kuang-Tien General Hospital, Taichung 43302; ${ }^{2}$ Department of Nutrition, \\ Master Program of Biomedical Nutrition, Hungkuang University, Taichung 43302, Taiwan R.O.C.
}

Received January 31, 2018; Accepted July 6, 2018

DOI: $10.3892 /$ etm.2018.6939

\begin{abstract}
An imbalance in the helper T cells (Th)1/Th2 and regulatory $\mathrm{T}$ cells (Tregs)/Th17 ratios is believed to play a key role in asthmatic inflammatory responses. Fucoidan reportedly reduces the production of inflammatory factors. Nutritional intervention is an important tool in decreasing the severity of asthmatic disease. This study aimed to investigate the beneficial roles of oligo-fucoidan in balancing the $\mathrm{T}$ cell subtype ratios and reducing airway inflammation ex vivo. Peripheral blood mononuclear cells (PBMCs) were collected from 30 asthmatic subjects and 15 healthy subjects. Harvested PBMCs were stimulated and treated with or without oligo-fucoidan (100 or $500 \mu \mathrm{g} / \mathrm{ml})$ for $48 \mathrm{~h}$. Cell surface and intracellular cytokine markers were examined by flow cytometry. The pro-inflammatory factors in plasma and culture supernatants were measured using ELISA kits. We found that oligo-fucoidan increases the proportion of Th1 and Treg cells, but did not affect the proportion of Th2 and Th17 cells. Oligo-fucoidan also increased the levels of interferon- $\gamma$ and interleukin-10. Thus, we concluded that oligo-fucoidan might improve the imbalance in Th1/Th2 and Treg/Th17 ratios to reduce airway inflammation, which could be a potential adjuvant therapy for allergic asthma.
\end{abstract}

\section{Introduction}

Asthma is a chronic disease characterized by airway hyper responsiveness, inflammation, and remodeling (1). The global prevalence of asthma in adults is estimated to vary widely from 0.8 to $13.4 \%$ (2). In 2000, the morbidity rate of asthma in Taiwan was approximately $7.57 \%$; by 2011 , this value had

Correspondence to: Miss Ya-Ling Chiou, Department of Nutrition, Master Program of Biomedical Nutrition, Hungkuang University, No. 1018 Sec. 6 Taiwan Boulevard, Shalu, Taichung 43302, Taiwan R.O.C.

E-mail: chiouyl@sunrise.hk.edu.tw

${ }^{*}$ Contributed equally

Key words: oligo-fucoidan, asthma, inflammation, T cells, adjuvant therapy risen to approximately $11.53 \%$. In particular, the incidence of asthma in individuals aged 18-30 years old rose from $2.84 \%$ in 2000 to $11.85 \%$ in 2011 (3), a 4-fold increase in just 11 years. This demonstrates that asthma has become a common chronic disease and that attention must be given to its burden on health care and quality of life in Taiwan.

Asthma is marked by chronic airway inflammation. The respiratory submucosa of asthmatic patients has been found to be infiltrated by many inflammatory cells such as eosinophils, T cells, mast cell, neutrophils and dendritic cells during both asymptomatic periods and asthma episodes, resulting in the chronic and persistent inflammation of the patient's airway $(1,4-7)$. These inflammatory cells release a variety of cytokines, including interleukin (IL)-4, IL-5, IL-13, and chemokines. They also induce the expression of airway tissue adhesion molecules such as intracellular adhesion molecule-1, vascular cell molecule-1, and E-selectin. This induction contributes to the chronic and persistent inflammation. In turn, repeated inflammation of the airway causes epithelial cell injury, smooth muscle proliferation or hypotrophy, and secretory cell proliferation resulting in increased mucous production toward airway remodeling and cause airway hypersensitivity (8); this eventually results in asthmatic pathogenesis $(9,10)$. The immune mechanism of asthma is predominantly mediated by helper $\mathrm{T}$ (Th) 2 cells. The activated Th2 cells into the airways and increase in the levels of Th2-type cytokines (IL-4, IL-5, IL-13) and involve in the isotype switching of antibodies produced by B cells from $\operatorname{IgM}$ to IgE to induce airway inflammation (11). Th1 cells could inhibit the development of Th2 cells to have an inflammation inhibitory role in asthma (12). In recent years, some studies have pointed out that a Th17/regulatory $\mathrm{T}$ cells (Treg) imbalance can also play a role in chronic airway inflammation (9,13-15). Evidence suggests that an imbalance in the Th1/Th2 and Th17/Treg cell ratios establishes the asthmatic inflammatory response.

The cause of airway inflammation is complex and involves many cells and inflammatory factors; consequently, drugs that control airway inflammation target several different pathways that produce inflammatory factors. Drug-based strategies to control airway inflammation include the use of a corticosteroid or the combined use of an inhaled corticosteroid and a long-acting $\beta 2$ agonist (16). Some patients are concerned about the adverse effects of these drugs, and seek alternative treatment. Cell and animal experiments focused 
on nutritional adjunctive therapy, an alternative treatment, have shown that vitamins $\mathrm{A}, \mathrm{E}$, and $\mathrm{C}$, folate, and fish oil can relieve the symptoms of asthma (17). Another nutritional adjunctive therapy option is fucoidan. Fucoidan is a polysaccharide derived from brown seaweed extracts. It is structurally similar to a heparin molecule; it consists of repeating units of disaccharides containing an alpha-1, 3-linked fucose and an alpha-1, 4-linked fucose, forming an alpha-1, 3-backbone with branches attached at $\mathrm{C} 2$ positions $(18,19)$. Fucoidan is reported to possess antiviral, antioxidant, antimicrobial, anticoagulant, anticancer/antitumor, antiproliferative, and anti-inflammatory properties $(19,20)$. Treatment of atopic allergic reactions with various fucoidan extracts improves allergic responses and prevents or reduces the symptoms of allergic disease by regulating the immune response, including an alteration in the Th1/Th2 balance, an inhibition of IgE production, and a suppression of mast cells degranulation $(21,22)$. In our previous study, we found that oligo-fucoidan might reduce the proliferation of airway smooth muscle (ASM) cells (23). However, the effects of oligo-fucoidan on $\mathrm{T}$ cells during allergic disease remains unclear. In this study, peripheral blood mononuclear cells (PBMCs) from allergic asthmatic and non-asthmatic subjects were cultured and $\mathrm{T}$ cells were activated. We investigated the effects of oligo-fucoidan on the profiles of the $\mathrm{T}$ cells and the levels of cytokines produced during allergic inflammation.

\section{Materials and methods}

Study subjects. The subjects were selected from outpatients at Kuang-Tien General Hospital (Taichung, Taiwan R.O.C.). The inclusion criteria were (1) presence of allergic asthma, (2) absence of complicated underlying disease, (3) lack of history of upper or lower airway disease during the month before the study, and (4) not having received immunotherapy or intravenous steroids during the four weeks before the study (inhaled steroids were allowed). The exclusion criteria were malignancy, infection, pregnancy, or other systematic immune disease. These subjects were collected from from March 2016 to June 2016. Thirty patients with allergic asthma (13 women and 17 men) and 15 healthy subjects without allergic asthma ( 7 women and 8 men) were included in this study. Pulmonary function was assessed by spirometry according to the standards of the American Thoracic Society. All subjects were fully aware of the purpose and nature of the study, which was approved by Institutional Review Board (IRB) of Kuang-Tien General Hospital.

Asthma control test (ACT). The ACT is a simple test suitable for asthma patients (aged 12 years old and over) that helps patients determine their level of disease control in the past 4 weeks. The test contains five questions; the lowest score is 1 and the highest score is 5 for each item, A the lower score represents worse asthma control. The sum of the scores from the five questions is calculated, with 25 as the maximum. A total score $>19$ (excluding 19) indicates asthma control is good; a total score is $<19$ indicates asthma control is poor (24).

Analysis of basic data and biochemical data of subjects. We collected anthropometric data, including body weight and height, and blood pressure from subjects using standardized techniques (IRB approved). Heparinized blood was collected to measure levels of alanine aminotransferase (ALT), aspartate aminotransferase (AST), blood urea nitrogen (BUN), and creatinine (Cre) in the hospital's inspection department. The total plasma IgE level was determined using the Two-site Sandwich Immunoassay Automated Chemiluminescence System (Centaur XP Immunoassay System, Siemens Healthcare Diagnostics, Tarrytown, NY, USA). The remaining blood was separated into plasma and cells. Plasma was stored as aliquots in liquid nitrogen until analysis was performed.

PBMCs stimulation assay. PBMCs were isolated by Ficoll-Hypaque within $1 \mathrm{~h}$ of blood collection. Harvested PBMCs were washed twice with $1 \mathrm{X}$ phosphate-buffered saline (PBS) and resuspended at $2 \times 10^{6}$ cells $/ \mathrm{ml}$ in RPMI-1640 medium supplemented with $10 \%$ fetal bovine plasma, 100 units $/ \mathrm{ml}$ penicillin, $100 \mu \mathrm{g} / \mathrm{ml}$ streptomycin, and $2 \mathrm{mmol} / \mathrm{l} \mathrm{L}$-glutamine. Cells were stimulated with Con A $(5 \mu \mathrm{g} / \mathrm{ml}$; Sigma-Aldrich; Merck KGaA, Darmstadt, Germany) and cultured with or without oligo-fucoidan (100 or $500 \mu \mathrm{g} / \mathrm{ml}$; Hi-Q oligo-fucoidan ${ }^{\circledR}$ as gift from Hi-Q Marine Biotech International Ltd., New Taipei City, Taiwan (R.O.C.)

Taiwan) for $48 \mathrm{~h}$. After incubation, the cells were centrifuged at $1,200 \mathrm{rpm}$ for $10 \mathrm{~min}$. The cell pellets were harvested for flow cytometry analysis (Beckman Coulter Epics xL; Beckman Coulter, Inc., Brea, CA, USA). The supernatants from the PBMCs stimulation assay were harvested and frozen at $-20^{\circ} \mathrm{C}$ until analysis was performed. Oligo-fucoidan was prepared by enzymatic hydrolysis of the original fucoidan from the brown algae Sargassum hemiphyllum to obtain molecules of approximately $0.5-0.8 \mathrm{kDa}(92.1 \%)$. The oligo-fucoidan was dissolved in double distilled water (weight/volume) and filtered with a $0.45 \mu \mathrm{m}$ sterile filter (Merck Millipore, Darmstadt, Germany).

Analysis of $T$ cell subtypes. PBMCs were re-stimulated with $50 \mathrm{ng} / \mathrm{ml}$ phorbol myristate acetate (PMA; Alexis Biochemicals, San Diego, CA, USA) and $1 \mu \mathrm{M}$ ionomycin (Sigma-Aldrich; Merck KGaA) in the presence of $1 \mu \mathrm{l} / \mathrm{ml}$ monensin (BD Biosciences, Franklin Lakes, NJ, USA) for $4 \mathrm{~h}$ after Con A stimulation (modified form) (25). Half of the total re-stimulated cells were incubated with phycoerythrin (PE)-conjugated anti-human CD3 antibodies for $20 \mathrm{~min}$ at $4^{\circ} \mathrm{C}$ in the dark and were separated to stain with fluorescein isothiocyanate (FITC)-conjugated anti-human CD4, anti-human CD8, or anti-human CD25 antibodies. The remaining re-stimulated cells were stained with FITC-conjugated anti-human CD4 and then suspended in fixation and permeabilization solution, to stain with PE-conjugated anti-human IFN- $\gamma$, anti-human IL-4, anti-human IL-17A, or anti-human Foxp3 antibodies. PE-conjugated mouse IgG1 antibodies were used as isotype controls. These antibodies were purchased from BD Biosciences.

Analysis of the levels of cytokines. The supernatants from the PBMCs stimulation assay and plasma were used to analyze the levels of cytokines including, IFN- $\gamma$, IL-4, IL-17A and IL-10 using ELISA kits (eBioscience, San Diego, CA, USA). All samples were analyzed in triple. 
Table I. Patient characteristics.

\begin{tabular}{|c|c|c|}
\hline Characteristic & $\begin{array}{c}\text { Asthma } \\
\text { group }(n=30)\end{array}$ & $\begin{array}{l}\text { Non-asthma } \\
\text { group }(n=15)\end{array}$ \\
\hline Age & $59.7 \pm 10.9$ & $59.8 \pm 7.0$ \\
\hline $\operatorname{Sex}(M / F)$ & $17 / 13$ & $8 / 7$ \\
\hline BMI & $24.8 \pm 4.2$ & $25.5 \pm 2.9$ \\
\hline $\operatorname{AST}(\mathrm{U} / \mathrm{l})$ & $21.4 \pm 6.38$ & $29.7 \pm 10.7^{b}$ \\
\hline ALT (U/l) & $19.8 \pm 10.5$ & $32.1 \pm 26.6$ \\
\hline BUN (mg/dl) & $16.1 \pm 7.21$ & $17.5 \pm 5.7$ \\
\hline Creatinine (mg/dl) & $1.1 \pm 1.0$ & $0.9 \pm 0.3$ \\
\hline TG (mg/dl) & $140 \pm 78.8$ & $125.5 \pm 61.2$ \\
\hline Choloesterol (mg/dl) & $203.7 \pm 33.7$ & $181.3 \pm 42.7$ \\
\hline WBC $\left(10^{3} / \mathrm{ul}\right)$ & $6.8 \pm 1.4$ & $5.7 \pm 1.6$ \\
\hline Eosinophil (\%) & $3.8 \pm 3.6$ & $3.6 \pm 2.1$ \\
\hline Total IgE (kUA/l) & $337 \pm 441$ & $43.8 \pm 32.0^{\mathrm{b}}$ \\
\hline ACT score & $22.4 \pm 1.7$ & N.D. \\
\hline $\mathrm{FVC}(\mathrm{L})$ & $2.6 \pm 0.8$ & N.D. \\
\hline $\mathrm{FEV}(\mathrm{L})$ & $1.6 \pm 0.5$ & N.D. \\
\hline FEV1/FVC pr & $62.7 \pm 11.5$ & N.D. \\
\hline \multicolumn{3}{|c|}{$\begin{array}{l}\text { Asthma severity classification }{ }^{a} \\
\text { before treatment, } \mathrm{n}(\%)\end{array}$} \\
\hline Mild persistent & $6(20)$ & \\
\hline Moderate persistent & $21(70)$ & \\
\hline Severe persistent & $3(10)$ & \\
\hline \multicolumn{3}{|c|}{$\begin{array}{l}\text { Stepwise pharmacologic } \\
\text { therapy }(\%)\end{array}$} \\
\hline Step 1 & 50 & \\
\hline Step 2 & 50 & \\
\hline
\end{tabular}

BMI, body mass index; AST, aspartate aminotransferase; ALT, alanine aminotransferase; BUN, blood urea nitrogen; TG, Triglyceride; WBC, white blood cell; ACT, asthma control test; N.D., not determined; pr, predicted; ${ }^{a}$ using GINA guide classification system; ${ }^{b}$ significant different compared to asthma subject $(\mathrm{P}<0.05)$. The results are expressed as the mean \pm SD unless otherwise indicated.

Statistical analysis. The results were expressed as the mean \pm SD. SPSS for Windows (SPSS Inc., Chicago, IL, USA) was used for the statistical analyses. Statistical significance was determined by the unpaired $t$-test for comparisons between the Asthma and Non-asthma groups and was determined by one-way ANOVA with the least significant difference post hoc test for comparisons between different treatment groups. Two-tailed statistical tests were used, and $\mathrm{P}<0.05$ was considered to indicate a statistically significant difference.

\section{Results}

Patient characteristics. Thirty-two asthmatic patients were recruited; however, complete data were not available for two patients. Thus, 30 asthmatic patients (Asthma group) and 15 healthy volunteers (Non-asthma group) were included in the study. The asthma severity of the patients using GINA guide classification system and Stepwise pharmacologic therapy. Basic demographic characteristics for the two groups were shown in Table I. There was no significant difference between the two groups for most components, except AST and total $\operatorname{IgE}$ levels $(\mathrm{P}<0.05)$. The subjects in the Asthma group had lung function below the normal range (FEV1/FVC predicted (pr), forced expiratory flow (FEF) (25-75\%) pr, FEV1 po, and FEF (25-75\%) po). The average ACT score was $22.4 \pm 1.7$. There were 29 asthmatic patients over 19 , indicating that the asthma symptoms in these patients were well-controlled.

Oligo-fucoidan increased the Th1/Th2 ratio. PBMCs were treated with different concentrations of oligo-fucoidan (OF100, $100 \mu \mathrm{g} / \mathrm{ml}$ and OF500: $500 \mu \mathrm{g} / \mathrm{ml}$ ) for $48 \mathrm{~h}$ in stimulated (treated Con A) condition. Oligo-fucoidan treatment increased the proportion of $\mathrm{CD}^{+} \mathrm{CD}^{+} \mathrm{T}$ cells in the Asthma group more than it did in the Non-asthma group, but the difference was not significant (Table II).

Following $\mathrm{T}$ cell stimulation, oligo-fucoidan treatment increased the proportion of $\mathrm{CD}^{+}{ }^{+} \mathrm{IFN}-\gamma^{+}$cells in the Asthma

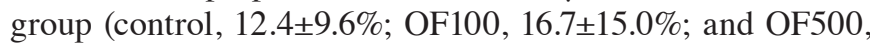
$16.6 \pm 12.5 \%)$ more so than in the Non-asthma group $(\mathrm{P}<0.05)$. In Fig. 1 showed T cells of one asthmatic and one non-asthmatic subject post-stimulation. Oligo-fucoidan further increased proportion of $\mathrm{CD}^{+}{ }^{+} \mathrm{IFN}-\gamma^{+}$cells in OF 100 group in asthma subject. On the other hand, the oligo-fucoidan treatment did not affect the proportion of $\mathrm{CD} 4^{+} \mathrm{IL}-4^{+}$cells in either of these two groups. However, there was no significant difference between the Asthma group and Non-asthma group in the magnitude of the increase in the proportion of $\mathrm{CD}^{+}$IFN- $\gamma^{+}$cells following $\mathrm{T}$ cell stimulation; this increase was calculated by subtracting the proportion of $\mathrm{CD}^{+}$IFN- $\gamma^{+}$cells observed under unstimulated conditions from the proportion observed under stimulated conditions (Fig. 2).

While oligo-fucoidan treatment increased the ratio of Th1/Th2 (IFN- $\gamma^{+} / \mathrm{IL}-4^{+}$) cells in the Asthma group, the increase was not significant (Table II). However, the oligo-fucoidan treatment, especially oligo-fucoidan treatment with $100 \mu \mathrm{g} / \mathrm{ml}$, did significantly increase the ratio of Th1/Th2 (IFN- $\left.\gamma^{+} / \mathrm{IL}-4^{+}\right)$cells following $\mathrm{T}$ cell stimulation in the Asthma group $(\mathrm{P}<0.05)$, but not in the Non-asthma group (Fig. 3).

Concentration of Th1 and Th2 cell cytokines in plasma and culture medium. Heparinized peripheral blood $(20 \mathrm{ml})$ was collected from each subject in both groups and separated into plasma and PBMCs. Plasma levels of IFN- $\gamma$ (a Th1 cytokine) and IL-4 (a Th2 cytokine) were assayed using ELISA kits (Table III). There were no differences between the cytokine levels in either of the two groups.

IFN- $\gamma$ and IL-4 levels in the culture medium of stimulated and unstimulated PBMCs from the patients were also assayed. Treatment with oligo-fucoidan increased the level of IFN- $\gamma$ $(\mathrm{P}<0.05)$, but did not affect the level of IL-4 in the Asthma group (Table III). These results mirror the proportions of Th1 and Th2 cells (Table II). In addition, treatment with oligo-fucoidan more reduced the level of IL-4 and increased the level of IFN- $\gamma$ more notably in the Non-asthma group than in the Asthma group $(\mathrm{P}<0.05)$.

Oligo-fucoidan increased the Treg/Th17 ratio. The proportion of $\mathrm{CD} 4^{+} \mathrm{IL}-17^{+} \mathrm{T}$ cells was higher in the Asthma group than in 
Table II. Changes in Th1 cell subtypes after different OF treated-PBMCs from two groups of subjects.

\begin{tabular}{|c|c|c|c|c|c|c|}
\hline \multirow[b]{3}{*}{ Subtype } & \multicolumn{6}{|c|}{ Proportions of cells (\%) } \\
\hline & \multicolumn{3}{|c|}{ Asthma group $(n=30)$} & \multicolumn{3}{|c|}{ Non-asthma group $(n=15)$} \\
\hline & Control & OF 100 & OF 500 & Control & OF 100 & OF 500 \\
\hline $\mathrm{CD}^{+}{ }^{+} \mathrm{CD} 4^{+}$ & $23.9 \pm 13.4$ & $26.1 \pm 12.8$ & $25.6 \pm 13.0$ & $22.2 \pm 13.4$ & $26.8 \pm 13.6$ & $21.5 \pm 12.5$ \\
\hline $\mathrm{CD} 4^{+} \mathrm{IL}_{-} 4^{+}$ & $0.3 \pm 0.34$ & $0.5 \pm 1.4$ & $0.3 \pm 0.4$ & $0.5 \pm 0.4$ & $0.7 \pm 0.6$ & $0.6 \pm 0.5$ \\
\hline $\mathrm{CD} 4^{+} \mathrm{IFN}-\gamma^{+}$ & $12.4 \pm 9.6$ & $16.7 \pm 15.0^{\mathrm{a}}$ & $16.6 \pm 12.5^{\mathrm{a}}$ & $14.5 \pm 7.0$ & $21.8 \pm 11.2^{\mathrm{a}}$ & $19.3 \pm 10.0$ \\
\hline $\mathrm{IFN}-\gamma^{+} / \mathrm{IL}^{-} 4^{+}$ & $52.0 \pm 48.4$ & $113.4 \pm 136.8$ & $80.4 \pm 88.2$ & $37.4 \pm 29.1$ & $54.2 \pm 45.2$ & $60.9 \pm 59.1$ \\
\hline
\end{tabular}

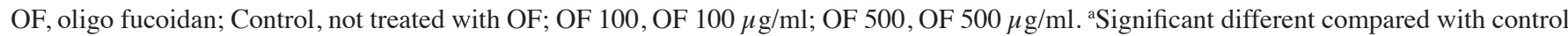
group among groups. IL, interleukin; PBMCs, peripheral blood mononuclear cells; OF, oligo fucoidan.

Table III. Concentration of Th1 and Th2 cell cytokines in plasma and culture medium.

\begin{tabular}{|c|c|c|c|c|}
\hline \multirow[b]{2}{*}{ Concentration (pg/ml) } & \multicolumn{2}{|c|}{ Asthma group $(\mathrm{n}=30)$} & \multicolumn{2}{|c|}{ Non-asthma group $(n=15)$} \\
\hline & Control & OF 100 & Control & OF 100 \\
\hline \multicolumn{5}{|l|}{ Plasma } \\
\hline IL-4 & $0.15 \pm 0.36$ & & $0.18 \pm 0.32$ & \\
\hline $\mathrm{IFN}-\gamma$ & $0.1 \pm 0.09$ & & $0.11 \pm 0.08$ & \\
\hline \multicolumn{5}{|l|}{ Culture medium } \\
\hline IL-4 & $0.14 \pm 0.05$ & $0.12 \pm 0.03$ & $0.20 \pm 0.05$ & $0.14 \pm 0.03^{\mathrm{a}, \mathrm{b}}$ \\
\hline IFN- $\gamma$ & $2.56 \pm 0.20$ & $2.71 \pm 0.34^{\mathrm{a}}$ & $2.62 \pm 0.09$ & $2.85 \pm 0.06^{\mathrm{a}, \mathrm{b}}$ \\
\hline
\end{tabular}

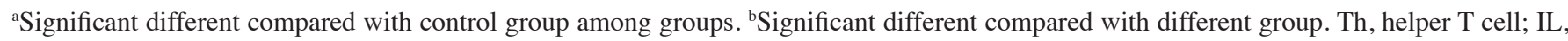
interleukin; OF, oligo fucoidan.

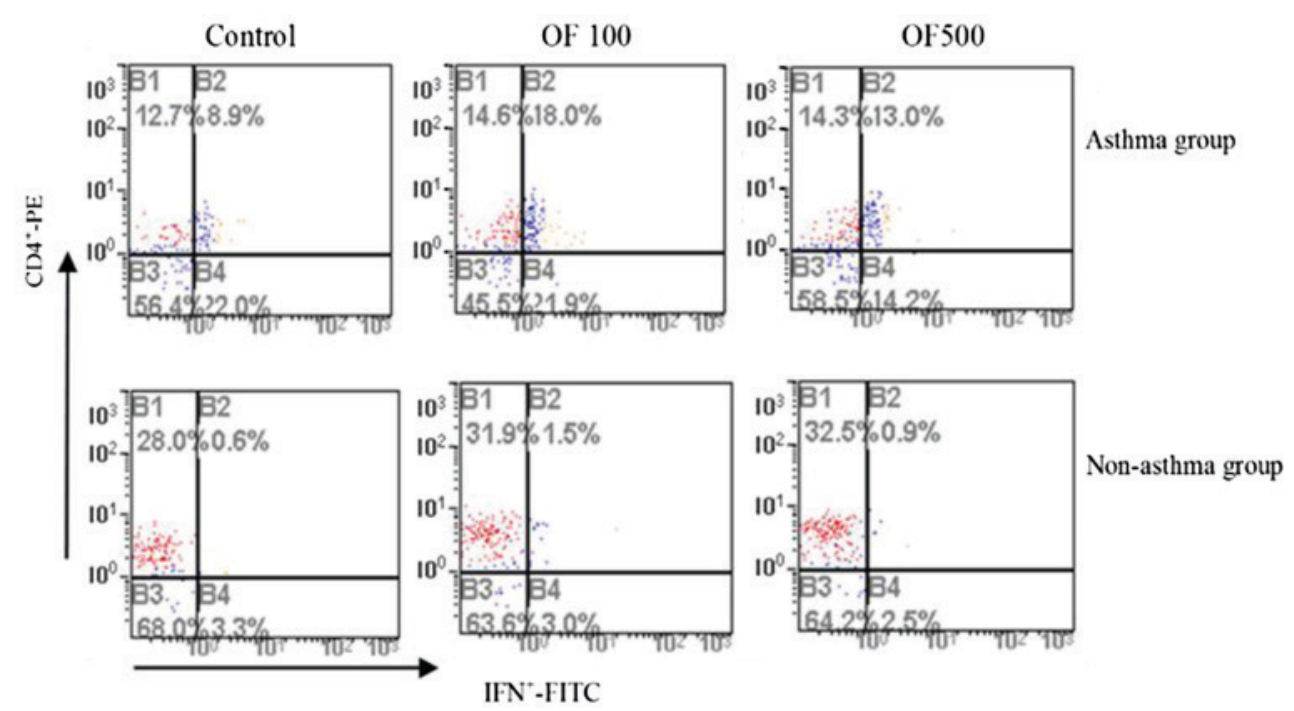

Figure 1. The level of $\mathrm{CD}^{+} \mathrm{IFN}^{+}$cells after OF treatment of PBMCs. PBMCs from asthmatic and non-asthmatic subjects were stimulated and treated with or without $\mathrm{OF}(100$ or $500 \mu \mathrm{g} / \mathrm{ml})$ for $48 \mathrm{~h}$. The populations of $\mathrm{CD}^{+} \mathrm{IFN}^{+}$cells were assayed by flow cytometry. Control, PBMCs not treated with OF; OF 100 , PBMCs were treated with $100 \mu \mathrm{g} / \mathrm{ml}$ OF for $48 \mathrm{~h}$; OF 500, PBMCs were treated with $500 \mu \mathrm{g} / \mathrm{ml} \mathrm{OF}$ for $48 \mathrm{~h}$. PBMCs, peripheral blood mononuclear cells; IL, interleukin; OF, oligo fucoidan.

the Non-asthma group $(7.3 \pm 12.1$ vs. $0.3 \pm 0.3 ; \mathrm{P}<0.05)$ (Table IV). Treatment with oligo-fucoidan decreased the proportions of $\mathrm{CD} 4^{+} \mathrm{IL}-17^{+}$cells in both groups, but the difference were not significant. There were also no significant differences between the two groups in the magnitude of the decrease in the proportion of $\mathrm{CD} 4^{+} \mathrm{IL}-17^{+}$cells following stimulation (data not shown). 


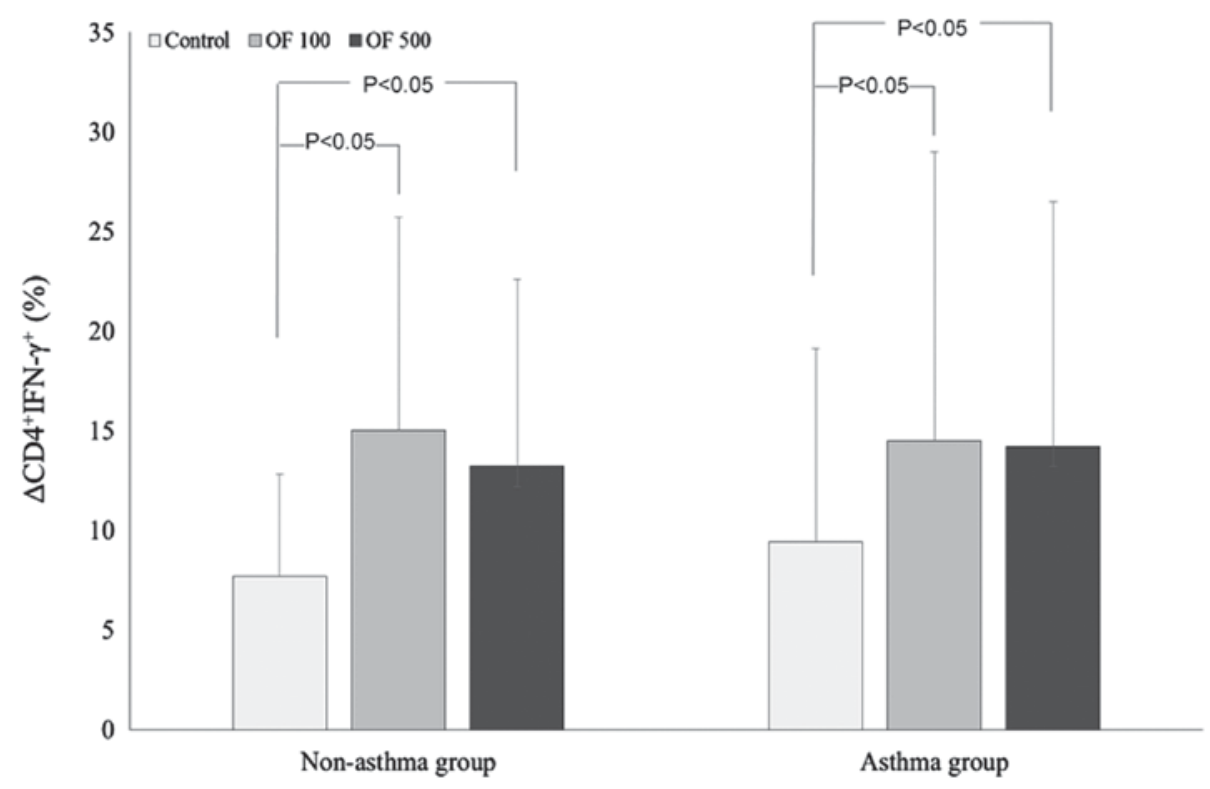

Figure 2. The degree of increasing of $\mathrm{CD}^{+} \mathrm{IFN}^{+}$cells after OF treatment of PBMCs. PBMCs from asthmatic and non-asthmatic subjects were separated into unstimulated and stimulated groups. These cells were treated with or without $\mathrm{OF}(100$ or $500 \mu \mathrm{g} / \mathrm{ml})$ for $48 \mathrm{~h}$. The populations of CD4 $4^{+}$IFN ${ }^{+}$cells were assayed by flow cytometry. Control, PBMCs not treated with OF; OF 100, PBMCs were treated with $100 \mu \mathrm{g} / \mathrm{ml} \mathrm{OF}$ for $48 \mathrm{~h}$; OF 500, PBMCs were treated with $500 \mu \mathrm{g} / \mathrm{ml} \mathrm{OF}$ for $48 \mathrm{~h} . \Delta \mathrm{CD}^{+} \mathrm{IFN}^{+}=$the level of $\mathrm{CD}^{+}{ }^{+} \mathrm{IFN}^{+}$cells from stimulated cells minus the level of $\mathrm{CD}^{+} \mathrm{IFN}^{+}$cells from unstimulated cells. OF, oligo fucoidan; PBMCs, peripheral blood mononuclear cells.
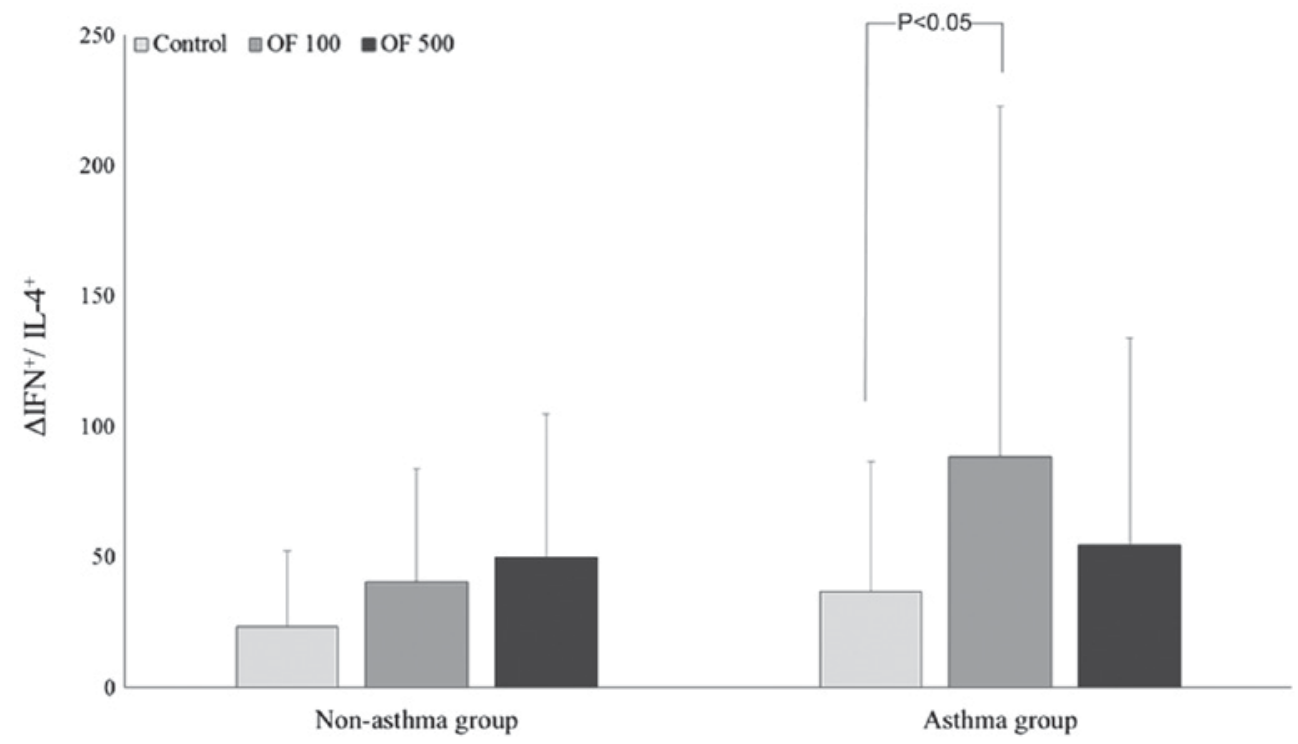

Figure 3. The degree of increasing of IFN $\mathrm{IIL}^{+} 4^{+}$ratio after OF treatment of PBMCs. PBMCs from asthmatic and non-asthmatic subjects were separated into unstimulated and stimulated groups. These cells were treated with or without OF (100 or $500 \mu \mathrm{g} / \mathrm{ml})$ for $48 \mathrm{~h}$. The populations of CD4 $4^{+}$IFN ${ }^{+}$cells and CD4 $4^{+}$ $\mathrm{IL}-4^{+}$cells were assayed by flow cytometry. Control, PBMCs not treated with OF; OF 100, PBMCs were treated with $100 \mu \mathrm{g} / \mathrm{ml}$ OF for $48 \mathrm{~h}$; OF 500 , PBMCs were treated with $500 \mu \mathrm{g} / \mathrm{ml} \mathrm{OF}$ for $48 \mathrm{~h} . \Delta \mathrm{IFN}^{+} / \mathrm{IL}^{-} 4^{+}$ratio=the level of IFN $/ / \mathrm{IL}_{-} 4^{+}$form stimulated cells minus the level of IFN ${ }^{+} / \mathrm{IL}^{-} 4^{+}$form unstimulated cells; OF, oligo fucoidan; PBMCs, peripheral blood mononuclear cells.

In asthmatic subjects, oligo-fucoidan treatment increased the proportion of Treg cells (CD4+Foxp3 $3^{+}$cells) significantly (control: $41.1 \pm 8.57 \%$, OF100: $47.6 \pm 7.4 \%$, and OF500: $49.4 \pm 7.4$ $(\mathrm{P}<0.05)$ (Table IV).

Oligo-fucoidan treatment increased the ratio of Treg/Th17 $\left(\mathrm{FOXP}^{+} / \mathrm{IL}-17^{+}\right)$in both the Asthma and Non-asthma groups (Table IV). However, there was no significant difference between the two regarding the degree of the Treg/Th17 ratio change following stimulation (data not shown).
Concentration of Treg and Th17 cell cytokines in plasma and culture medium. Plasma levels of IL-10 (a Treg cytokine) and IL-17 (a Th17 cytokine) were assayed using ELISA kits (Table V). There were no differences between the cytokine levels in the Asthma and Non-asthma groups. The levels of IL-10 and IL-17 from the culture medium of PBMCs from the patients were also assayed. The levels of IL-10 in Asthma group were higher than those in the Non-asthma group, but the difference was not significant. In addition, oligo-fucoidan increased 
Table IV. The changes of Treg cell subtypes after different OF treated-PBMCs from two groups of subjects.

\begin{tabular}{|c|c|c|c|c|c|c|}
\hline & \multicolumn{3}{|c|}{ Asthma group $(n=30)$} & \multicolumn{3}{|c|}{ Non-asthma group $(n=15)$} \\
\hline & Control $^{1}$ & OF $100^{2}$ & OF $500^{3}$ & Control & OF 100 & OF 500 \\
\hline \multicolumn{7}{|c|}{ Proportions of cells (\%) } \\
\hline $\mathrm{CD} 4^{+} \mathrm{IL}-17^{+}$ & $7.3 \pm 12.1$ & $6.8 \pm 11.6$ & $6.7 \pm 12.4$ & $0.3 \pm 0.3^{\mathrm{b}}$ & $0.4 \pm 0.4^{\mathrm{b}}$ & $0.3 \pm 0.2^{\mathrm{b}}$ \\
\hline $\mathrm{CD}^{+} \mathrm{FOXP}^{+}$ & $41.13 \pm 8.7$ & $47.6 \pm 7.4^{\mathrm{a}}$ & $49.4 \pm 7.4^{\mathrm{a}}$ & $38.4 \pm 15.4$ & $45.6 \pm 13.8$ & $47.0 \pm 14.4^{\mathrm{a}}$ \\
\hline $\mathrm{FOXP}^{+} / \mathrm{IL}-17^{+}$ & $165.9 \pm 120.5$ & $224.3 \pm 164.1$ & $219.8 \pm 169.1$ & $196.6 \pm 139.2$ & $197.7 \pm 130.8$ & $208.8 \pm 161.8$ \\
\hline
\end{tabular}

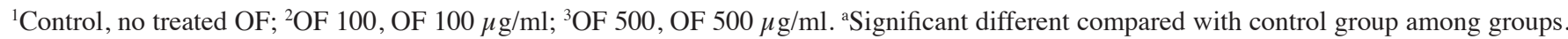
${ }^{\mathrm{b} S i g n i f i c a n t}$ different compared with different group. Tregs, regulatory T cells; OF, oligo fucoidan; PBMCs, peripheral blood mononuclear cells; IL, interleukin.

Table V. Concentration of Treg and Th17 cell cytokines in plasma and culture medium.

\begin{tabular}{|c|c|c|c|c|}
\hline \multirow[b]{2}{*}{ Concentration $\mathrm{pg} / \mathrm{ml}$} & \multicolumn{2}{|c|}{ Asthma group $(n=30)$} & \multicolumn{2}{|c|}{ Non-asthma group $(n=15)$} \\
\hline & Control & OF 100 & Control & OF 100 \\
\hline \multicolumn{5}{|l|}{ Plasma } \\
\hline IL-10 & $0.11 \pm 0.11$ & $3.17 \pm 0.12^{\mathrm{a}}$ & $0.18 \pm 0.30$ & $2.92 \pm 0.07^{\mathrm{a}, \mathrm{b}}$ \\
\hline IL-17A & $0.15 \pm 0.31$ & $3.01 \pm 0.21$ & $0.30 \pm 0.60$ & $3.04 \pm 0.12$ \\
\hline \multicolumn{5}{|l|}{ Culture medium } \\
\hline IL-10 & $2.04 \pm 0.57$ & & $1.89 \pm 0.53$ & \\
\hline IL-17A & $2.50 \pm 0.62$ & & $2.81 \pm 0.32^{\mathrm{b}}$ & \\
\hline
\end{tabular}

${ }^{\text {aS }}$ ignificant different compared with control group among groups. ${ }^{\mathrm{b}}$ Significant different compared with different group. OF, oligo fucoidan; IL, interleukin; Tregs, regulatory T cells; Th, helper T cells.

the level of IL-10 in both the Asthma and Non-asthma groups $(\mathrm{P}<0.05)($ Table V). The levels of IL-17 in Asthma group were lower than those in Non-asthma group $(\mathrm{P}<0.05)$. In addition, oligo-fucoidan more increased the level of IL-17 than control group in the Asthma and Non-asthma groups, but the difference was not significant.

\section{Discussion}

The asthmatic immune response favors the production of Th2 cells over Th1 cells. Th1 cells may inhibit Th2 cell differentiation, effectively reducing the Th2-induced asthmatic response (26). However, excessive IFN- $\gamma$ release by Th1 cells can also cause airway inflammation (27). Therefore, an increase in the proportion of Th1 cells during allergic asthma is not necessarily a good phenomenon. In this study, we found that the proportion of Th1 cells and the level of IFN- $\gamma$ were significantly lower in asthmatic subjects than in non-asthmatic subjects (Tables II and III), and that treatment with oligo-fucoidan caused an increase in the proportion of Th1 cells and in the level of IFN- $\gamma$ in asthmatic subjects. However, there was no significant difference in the degree to which stimulating the cells increased in the proportion of Th1 cells and IFN- $\gamma$ levels between the Asthma and Non-asthma groups (Fig. 2). This suggests that oligo-fucoidan treatment might not overmuch increase the Th1 immune response, which causes airway inflammation. Oligo-fucoidan treatment also increased the Th1/Th2 ratio, suggesting that it might reduce airway inflammation.

Because Th2 cells mediate airway inflammatory responses in allergic asthma, some drugs that reduce the number of Th2 cells, such as corticosteroids, are used to control airway inflammation $(13,28)$. In this study, the asthmatic subjects all use corticosteroids to successfully control their asthmatic symptoms (Table I). There were no differences in the proportion of Th2 cells or IL-4 levels between asthmatic patients and healthy subjects that might be caused by these drugs. However, it is worth noting that oligo-fucoidan reduced the proportion of Th 2 cells in unstimulated $\mathrm{T}$ cells. When the $\mathrm{T}$ cells of asthma patients were stimulated, oligo-fucoidan treatment did not effectively reduce the proportion of Th 2 cells; however, the proportion of Th 2 cells did not increase. This, may be due to the increased proportion of Th1 cells, which may reduce the Th 2 cells-mediated airway inflammation. Although the inflammatory response in allergic asthma is predominantly Th2-mediated, Th17 cells also cause airway inflammation through IL-17A/F and IL-22 production and play an important role in the pathology of asthma (29). Th17 cells and the cytokines produced by Th17 cells increase airway inflammation through neutrophil and eosinophil activation (30-33). In this study, we found a larger population of Th17 cells in asthmatic subjects than in non-asthmatic subjects (Table IV) $(\mathrm{P}<0.05)$. In addition, oligo-fucoidan treatment had 
a tendency to decrease the proportion of Th17 cells in both groups.

Human Treg cells not only express CD25 on their cell surface, but also express the forkhead box P3 (Foxp3) transcription factor and are important in the establishment and maintenance of an immunosuppressive response (34-36). Treg cells can suppress other T cell subtypes by producing TGF- $\beta$ and IL-10 and function of Treg cells may be reduced in asthma (37). In this study, we found that oligo-fucoidan treatment significantly increased the proportion of Treg cells and the IL-10 levels (Tables IV and $\mathrm{V}$ ) in asthmatic subjects. It is now known that Treg cells reduce $\mathrm{T}$ cell-induced inflammation by producing IL-10. However, the detailed mechanism of inflammation inhibition in Treg cell-mediated allergic asthma remain unclear.

Recent studies indicate that fucoidan can improve allergic responses by regulating the immune response, including alterations in the Th1/Th2 balance, inhibiting the production of IgE, suppressing the degranulation of mast cells, and inhibiting the proliferation of ASM (23). At present, little has been done to explore on the use of fucoidan in allergic diseases. This study was the first to characterize the immunomodulatory effects of oligo-fucoidan in the cells of asthmatic patients and emphasized its potential mechanism as a pharmaceutical and nutraceutical for the adjuvant therapy of allergic asthma. In this study, we compared the $\mathrm{CD}^{+}{ }^{+} \mathrm{T}$ cell profiles of asthmatic and non-asthmatic subjects and assessed the effects of oligo-fucoidan treatment on these profiles. Our results showed that oligo-fucoidan treatment could increase the ratios of Th1/Th2 and Treg/Th17 cells. Oligo-fucoidan might act on one or more of membrane receptors found on the immune cells include macrophages, dendritic cells to activate $\mathrm{T}$ cells toward $\mathrm{Th} 1$ differenation and producing IFN or toward Treg differenation and producing IL-10. The mechanism which Oligo-fucoidan affects the differentiation of $\mathrm{T}$ cells is still unclear. Oligo-fucoidan might, like $\beta$-glucan, act on one or more of membrane receptors found on the immune cells including macrophages, dendritic cells to activate $\mathrm{T}$ cells and induce Th 1 differenation and producing IFN or influence Treg differenation and producing IL-10.

There are some studies which indicate that non oligo-fucoidan significantly reduces IgE production by B cells in PBMCs in vitro and in vivo (38-40). In this present study, we found that oligo-fucoidan significantly increased IFN- $\gamma$ production in PBMCs of asthmatic patients but did not affect IL-4 production. Our results suggest that oligo-fucoidan treatment has beneficial effects for allergic airway inflammation.

CD44 is a cell surface glycoprotein and the two main ligands for CD44 are hyaluronan (HA) and osteopontin (OPN) $(41,42)$. On surface of the T cells, there is more expression of CD44 on activated $\mathrm{T}$ cells than naïve $\mathrm{T}$ cells (43). In allergic asthma, Th2 cells infiltrate the ASM layer and may cause ASMCs proliferation and inflammation. In vitro studies have shown that $\mathrm{T}$ cells adhere to ASMCs via CD44 to induce ASMCs proliferation (44). However, this study did not indicate what subtype of T cells to cause this phenomenon. In the other study indicated CD44 can inhibit cell death regulated by Fas (45). However, other study also indicated CD44 only regulates the survival of Th1 cells, but has no effect on Th2 or Th17 cells. Treatment of Th1 cells with CD44 agonist antibodies has been shown to increase cell survival by activating downstream PI3K-Akt pathways (46). In our study also found treatment with oligo-fucoidan caused an increase in the proportion of Th1 cells and in the level of IFN- $\gamma$ in asthmatic subjects, but had no effect on Th2 or Th17 cells. In our previous study, we also found that oligo-fucoidan might reduce the proliferation of ASM cells. CD44 also expressed on the surface of smooth muscle cells. The role of oligo-fucoidan in CD44 of cocultureTh1 cells and ASMCs remains to be clarified and this is also one of the focuses of future research. Some data do not show statistically significant differences due to the small sample size of the study. This in vitro experiment is preliminary to confirm the possibility of oligo-fucoidan for adjuvant treatment of asthma, and future research will be directed toward the role of oligo-fucoidan in conventional asthma therapy.

Oligo-fucoidan treatment can increase the ratio of Th1/Th2 and Treg/Th17 cells to ameliorate the imbalance in the T cell profile and could be a potential adjuvant therapy for allergic asthma. These results will provide the basis for future animal experiments and human trials.

\section{Acknowledgements}

Not applicable.

\section{Funding}

Equipment support for this study Hungkuang University and Kuang-Tien General Hospital and the financial support of Hi-Q Marine Biotech International, Ltd. (grant no. HK104-038). The authors had full access to all of the data from the study and take full responsibility for the integrity of the data and the accuracy of the data analysis.

\section{Availability of data and materials}

The datasets used or analyzed during the current study are available from the corresponding author.

\section{Authors' contributions}

All authors contributed extensively to the work presented in this paper. W-SK, C-HY and Y-LC designed the experiment. J-JT and C-JS performed the experiments. W-SK, C-HY, Y-LC and $\mathrm{J}-\mathrm{JT}$ analyzed the data and prepared the manuscript.

\section{Ethics approval and consent to participate}

Written informed consent was obtained from all patients for the present study, which was approved by IRB of Kuang-Tien General Hospital (approval no. 10457).

\section{Patient consent for publication}

Not applicable.

\section{Competing interests}

The authors declare that they have no competing interests.

\section{References}

1. Bochner BS, Undem BJ and Lichtenstein LM: Immunological aspects of allergic asthma. Annu Rev Immunol 12: 295-335, 1994. 
2. Anandan C, Nurmatov U, van Schayck OC and Sheikh A: Is the prevalence of asthma declining? Systematic review of epidemiological studies. Allergy 65: 152-167, 2010.

3. Ma YC, Lin CC, Yang SY, Chen HJ, Li TC and Lin JG: Time trend analysis of the prevalence and incidence of diagnosed asthma and traditional chinese medicine use among adults in taiwan from 2000 to 2011: A population-based study. PLoS One 10: e0140318, 2015.

4. Gleich GJ: Mechanisms of eosinophil-associated inflammation. J Allergy Clin Immunol 105: 651-663, 2000

5. Brightling CE, Bradding P, Symon FA, Holgate ST, Wardlaw AJ and Pavord ID: Mast-cell infiltration of airway smooth muscle in asthma. N Engl J Med 346: 1699-1705, 2002.

6. Kikuchi S, Kikuchi I, Takaku Y, Kobayashi T, Hagiwara K and Kanazawa M: Neutrophilic inflammation and CXC chemokines in patients with refractory asthma. Int Arch Allergy Immunol 149 (Suppl 1): S87-S93, 2009.

7. Lambrecht BN and Hammad H: Taking our breath away: Dendritic cells in the pathogenesis of asthma. Nat Rev Immunol 3: 994-1003, 2003.

8. Murdoch JR and Lloyd CM: Chronic inflammation and asthma. Mutat Res 690: 24-39, 2010

9. Corrigan CJ and Kay AB: T cells and eosinophils in the pathogenesis of asthma. Immunol Today 13: 501-507, 1992

10. Foster PS, Yang M, Herbert C and Kumar RK: CD4(+) T-lymphocytes regulate airway remodeling and hyper-reactivity in a mouse model of chronic asthma. Lab Invest 82: 455-462, 2002.

11. Larche M, Robinson DS and Kay AB: The role of T lymphocytes in the pathogenesis of asthma. J Allergy Clin Immun 111: 450-463, 2003.

12. Paul WE and Zhu JF: How are $\mathrm{T}(\mathrm{H}) 2$-type immune responses initiated and amplified? Nat Rev Immunol 10: 225-235, 2010.

13. Irvin C, Zafar I, Good J, Rollins D, Christianson C Gorska MM, Martin RJ and Alam R: Increased frequency of dual-positive TH2/TH17 cells in bronchoalveolar lavage fluid characterizes a population of patients with severe asthma. J Allergy Clin Immunol 134: 1175-1186.e7, 2014.

14. Hashimoto T, Akiyama K, Kobayashi N and Mori A: Comparison of IL-17 production by helper T cells among atopic and nonatopic asthmatics and control subjects. Int Arch Allergy Immunol 137 (Suppl 1): 51-54, 2005

15. Wei B, Zhang H, Li L, Li M and Shang Y: T helper 17 cells and regulatory $\mathrm{T}$-cell imbalance in paediatric patients with asthma. J Int Med Res 39: 1293-1305, 2011.

16. Tamm M, Richards DH, Beghe B and Fabbri L: Inhaled corticosteroid and long-acting $\beta 2$-agonist pharmacological profiles: Effective asthma therapy in practice. Respir Med 106 (Suppl 1): S9-S19, 2012.

17. Han YY, Forno E, Holguin F and Celedon JC: Diet and asthma: An update. Curr Opin Allergy Clin Immunol 15: 369-374, 2015.

18. Kusaykin M, Bakunina I, Sova V, Ermakova S, Kuznetsova T, Besednova N, Zaporozhets T and Zvyagintseva T: Structure, biological activity and enzymatic transformation of fucoidans from the brown seaweeds. Biotechnol J 3: 904-915, 2008.

19. Li B, Lu F, Wei X and Zhao R: Fucoidan: Structure and bioactivity Molecules 13: 1671-1695, 2008.

20. Wang J, Zhang Q, Zhang Z and Li Z: Antioxidant activity of sulfated polysaccharide fractions extracted from Laminaria japonica. Int J Biol Macromol 42: 127-132, 2008.

21. Yanase Y, Hiragun T, Uchida K, Ishii K, Oomizu S, Suzuki H, Mihara S, Iwamoto K, Matsuo H, Onishi N, et al: Peritoneal injection of fucoidan suppresses the increase of plasma IgE induced by OVA-sensitization. Biochem Biophys Res Commun 387: 435-439, 2009

22. Maruyama H, Tamauchi $\mathrm{H}$, Hashimoto $\mathrm{M}$ and Nakano $\mathrm{T}$ : Suppression of Th2 immune responses by mekabu fucoidan from Undaria pinnatifida sporophylls. Int Arch Allergy Immunol 137: 289-294, 2005

23. Yang CH, Tsao CF, Ko WS and Chiou YL: The oligo fucoidan inhibits platelet-derived growth factor-stimulated proliferation of airway smooth muscle cells. Mar Drugs 14: 15, 2016

24. Jia CE, Zhang HP, Lv Y, Liang R, Jiang YQ, Powell H, Fu JJ, Wang L, Gibson PG and Wang G: The asthma control test and asthma control questionnaire for assessing asthma control: Systematic review and meta-analysis. J Allergy Clin Immunol 131: 695-703, 2013.

25. Yokota A, Takeuchi H, Maeda N, Ohoka Y, Kato C, Song SY and Iwata M: GM-CSF and IL-4 synergistically trigger dendritic cells to acquire retinoic acid-producing capacity. Int Immunol 21: 361-377, 2009
26. Iwamoto I, Nakajima H, Endo $\mathrm{H}$ and Yoshida S: Interferon gamma regulates antigen-induced eosinophil recruitment into the mouse airways by inhibiting the infiltration of CD4+ T cells. J Exp Med 177: 573-576, 1993.

27. Hayashi N, Yoshimoto T, Izuhara K, Matsui K, Tanaka T and Nakanishi K: T helper 1 cells stimulated with ovalbumin and IL-18 induce airway hyperresponsiveness and lung fibrosis by IFN-gamma and IL-13 production. Proc Natl Acad Sci USA 104 14765-14770, 2007.

28. Pene J, Chevalier S, Preisser L, Venereau E, Guilleux MH, Ghannam S, Molès JP, Danger Y, Ravon E, Lesaux S, et al: Chronically inflamed human tissues are infiltrated by highly differentiated Th17 lymphocytes. J Immunol 180: 7423-7430, 2008

29. Peck A and Mellins ED: Plasticity of T-cell phenotype and function: The T helper type 17 example. Immunology 129: 147-153, 2010.

30. Korn T, Bettelli E, Oukka M and Kuchroo VK: IL-17 and Th17 cells. Annu Rev Immunol 27: 485-517, 2009.

31. Choy DF, Hart KM, Borthwick LA, Shikotra A, Nagarkar DR, Siddiqui S, Jia G, Ohri CM, Doran E, Vannella KM, et al: TH2 and TH17 inflammatory pathways are reciprocally regulated in asthma. Sci Transl Med 7: 301ra129, 2015.

32. Chesne J, Braza F, Mahay G, Brouard S, Aronica M and Magnan A: IL-17 in severe asthma. Where do we stand? Am J Respir Crit Care Med 190: 1094-1101, 2014

33. Zhao S, Jiang Y, Yang X, Guo D, Wang Y, Wang J, Wang R and Wang C: Lipopolysaccharides promote a shift from Th2-derived airway eosinophilic inflammation to Th17-derived neutrophilic inflammation in an ovalbumin-sensitized murine asthma model. J Asthma 54: 447-455, 2017.

34. Fontenot JD and Rudensky AY: A well adapted regulatory contrivance: Regulatory $\mathrm{T}$ cell development and the forkhead family transcription factor Foxp3. Nat Immunol 6: 331-337, 2005.

35. Hori S, Nomura T and Sakaguchi S: Control of regulatory $T$ cell development by the transcription factor Foxp3. Science 299: 1057-1061, 2003

36. Khattri R, Cox T, Yasayko SA and Ramsdell F: An essential role for Scurfin in CD4+CD25+ T regulatory cells. Nat Immunol 4: 337-342, 2003.

37. Barnes PJ: The cytokine network in asthma and chronic obstructive pulmonary disease. J Clin Invest 118: 3546-3556, 2008.

38. Iwamoto K, Hiragun T, Takahagi S, Yanase Y, Morioke S, Mihara S, Kameyoshi Y and Hide M: Fucoidan suppresses IgE production in peripheral blood mononuclear cells from patients with atopic dermatitis. Arch Dermatol Res 303: 425-431, 2011

39. Oomizu S, Yanase Y, Suzuki H, Kameyoshi Y and Hide M: Fucoidan prevents $\mathrm{C}$ epsilon germline transcription and $\mathrm{NF}$ kappaB p52 translocation for IgE production in B cells. Biochem Bioph Res Commun 350: 501-507, 2006.

40. Yanase Y, Hiragun T, Uchida K, Ishii K, Oomizu S, Suzuki H, Mihara S, Iwamoto K, Matsuo H, Onishi N, et al: Peritoneal injection of fucoidan suppresses the increase of plasma IgE induced by OVA-sensitization. Biochem Bioph Res Commun 387: 435-439, 2009.

41. Naor D, Nedvetzki S, Walmsley M, Yayon A, Turleyd EA, Golan I, Caspi D, Sebban LE, Zick Y, Garin T, et al: CD44 involvement in autoimmune Inflammations-The lesson to be learned from CD44-Targeting by antibody or from knockout mice. Ann Ny Acad Sci 1110: 233-247, 2007

42. Mummert ME: Immunologic roles of hyaluronan. Immunol Res 31: 189-205, 2005

43. Pure E and Cuff CA: A crucial role for CD44 in inflammation. Trends Mol Med 7: 213-221, 2001

44. Lazaar AL, Albelda SM, Pilewski JM, Brennan B, Pure E and Panettieri RA: T-lymphocytes adhere to airway smooth-muscle cells via integrins and cd44 and induce smooth-muscle cell-DNA synthesis. J Exp Med 180: 807-816, 1994.

45. Hauptschein RS, Sloan KE, Torella C, Moezzifard R, Giel-Moloney M, Zehetmeier C, Unger C, Ilag LL and Jay DG: Functional proteomic screen identifies a modulating role for CD44 in death receptor-mediated apoptosis. Cancer Res 65: 1887-1896, 2005.

46. Klingbeil P, Marhaba R, Jung T, Kirmse R, Ludwig T and Zoller M: CD44 variant isoforms promote metastasis formation by a tumor cell-matrix cross-talk that supports adhesion and apoptosis resistance. Mol Cancer Res 7: 168-179, 2009.

This work is licensed under a Creative Commons Attribution-NonCommercial-NoDerivatives 4.0 International (CC BY-NC-ND 4.0) License. 